\title{
Histone Gene
}

National Cancer Institute

\section{Source}

National Cancer Institute. Histone Gene. NCI Thesaurus. Code C148174.

A gene encoding a histone protein. 